MICHAE STAWOWIAK

ZENON ROŻENEK

\title{
An assessment of rope durability in mining shaft hoists
}

\begin{abstract}
The article presents the issues of the durability of lifting ropes and balance ropes operated in selected shafts of deep mines. The basic causes of hoisting ropes wear are described, the methods of steel ropes wear evaluation are given, as well as the hoisting ropes durability evaluation criteria. The authors also present selected results from the extension of hoisting ropes. The article ends with some conclusions resulting from the research. The article has also been provided with photos showing the measuring equipment used to assess the durability of steel and steel-rubber ropes. The article presents the criteria for assessing the durability of lifting ropes.
\end{abstract}

Key words: operation, ropes, assessment, durability

\section{INTRODUCTION}

Mining hoisting devices are the most important link and basic means of transport in the Polish hard coal mining industry. These devices are used to transport the excavated material from underground mines. Hoisting devices also perform a number of other functions, such as crew descent and departure, and lowering various types of materials necessary for the exploitation of the deposit, as well as the maintenance of the mine infrastructure [1].

The decreasing number of coal deposits lying in favour able mining and geological conditions and the constantly increasing depth of mining result in an increase in mining costs. If we add to this the relatively low coal prices on world markets, the true picture of hard coal mining in Poland and in the world emerges. A chance to improve the profitability of exploitation, and thus to maintain the profitability of Polish mines, is the increased concentration of extraction. This situation contributes to the need to use increasingly efficient and reliable extraction devices. This can be achieved by using extraction vessels of increasing capacity, as well as driving speeds in the extraction shafts. Such actions result in an increase in the operating parameters of the ropes, which reduces their durability [1-3].

Steel ropes used in shaft hoists are subject to various wear processes. They change their mechanical parameters, as a result of which they lose their operational properties. Ropes are subject to wear processes that are nonlinear as a function of time. Effects of foreseeable wear are counteracted by conducting regular tests and inspections using various methods, from visual to non-destructive [3-5].

In order to better understand the wear processes of ropes, it may be useful to carry out an analysis of their durability. The ropes operating in the downhill material shaft hoists in one of the selected hard coal mines were analyzed in this way. The source of the data were reports on tests periodically carried out by experts, books of periodical inspections of shaft hoists and books of shaft reports.

\section{METHODS OF ASSESSING THE CONDITION OF STEEL ROPES}

Several methods are used to assess the condition of a rope in service. We can distinguish two groups [4]:

- non-apparatus - based on observing wear processes or on measuring geometric features of ropes, the condition of which changes with the change of the rope condition,

- apparatus - involve the use of specialized apparatus. The most commonly used are magnetic tests [6]. 


\subsection{Non-apparatus methods}

\subsubsection{Visual method}

This method is based on visual observation of the condition of the available part of the rope. This is the most common diagnostic method to assess the condition of ropes. It requires a lot of experience of the person conducting the observations and due to the lack of unambiguous criteria, this method is not very objective. By performing the cyclic counting of wire fatigue scraps, this method can be used to prepare the fatigue wear characteristics of the ropes [4].

Visual observations reveal damage such as [7]:

- breaking strands,

- corrosion,

- wire fractures,

- change of rope diameter,

- deformities,

- waviness,

- rope attachment point.

\subsubsection{Methods of measuring the geometrical features of the rope}

The most common method of rope condition assessment in this group is the registration of changes in diameter in the determined rope cross-section. The reference is the nominal or actual dimension in the designated cross-section. The diameters are recorded after some time after putting on a new rope, when the diameter is clearly stabilized. The reduction in diameter at a given location is in most cases associated with a core damage or defect. The lateral rigidity of the rope decreases or increases, which has an impact on the acceleration of fatigue wear. The local increase of the rope's transverse stiffness and the dropping of strands onto the core are also dangerous. These phenomena in bent ropes can lead to fatigue scrap of wires [4].

Pattern example:

$$
\Delta d=\frac{d-d_{\text {nom }}}{d_{\text {nom }}} \cdot 100 \%
$$

where:

$d_{\text {nom }}$ - nominal rope diameter [mm],

$d$ - measured rope diameter [mm].

Another method forassessing the condition of ropes in this group is measuring the rope jump length. This is the length of the helix stroke that the individual strands draw. The pitch of ropes with steel cores is from 7 to 9 nominal diameters. In order to increase accuracy, the measurement is made at three times the stroke length. It should be performed in several marked sections. The reference is the actual or nominal size of the rope at the site. Measurement of the rope jump length is only justified after a certain time, different for each device and rope structure. This delay is to stabilize the elastic parameters of the rope (no elongation). When the jump length changes after this period, this may indicate twirling of the ropes. A significant difference in the stroke length compared to the nominal value affects the fatigue life reduction $[4,7]$ :

$$
\Delta l=\frac{l_{s}-l_{\text {nom }}}{l_{\text {nom }}} \cdot 100
$$

where:

$l_{\text {nom }}$ - nominal rope jump length [mm],

$l_{s}-$ measured rope jump length [mm].

\subsubsection{Methods of measuring the geometrical size of losses}

In order to measure the size of the wire friction, three methods are used: the method of measuring the diameter of the rope, the method of measuring the dimensions of the wear of a single wire, and the method of measuring the reflection surface of the rope in print. The method of measuring the diameters is used for semi-closed and closed ropes. It is the only method of measuring this size for them. This method consists in comparing the measured diameter with the diameter of the new rope. The method of measuring the dimensions of a single wire wear (Fig. 1) consists in measuring the wear height $\mathrm{h}$ or the wear chord $\mathrm{c}$. Measuring the wear chord is a very difficult task and burdened with a considerable degree of error. In order to measure the height of the wear, it is necessary to cut the wire. The size of the clash is calculated from the formula:

$$
\Delta S_{F e}=r^{2} \cdot \arcsin \left(\frac{c}{2 r}\right)-0.5 \cdot \sqrt{r^{2}-0.25 c^{2}}
$$

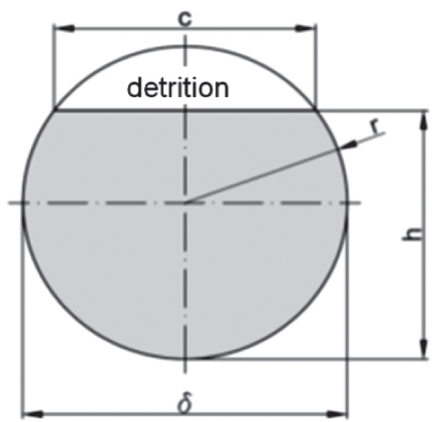

Fig. 1. Calculation of the wire wear area [8] $c$-wire wear chord, $h$-wire wear height, $\delta$ - wire diameter, $r$ - radius $(r=0.5 \cdot \delta)$ 
A more precise method of determining the wire wear chord is the "in print" method (Fig. 2). It consists in applying chalk, graphite or a paint designed for this purpose to the dirt-free surface of the rope. After making a mark on the paper, an image is obtained in which the wear surfaces are clearly visible. The bowstring can be measured very accurately, directly from a print or from a copy made to a suitable scale. In order to calculate the area of the scraped wire, the resulting chord size should be entered in formula (3). The values calculated using this method are usually lower than those calculated based on the direct measurement of the chord of clashes [1].

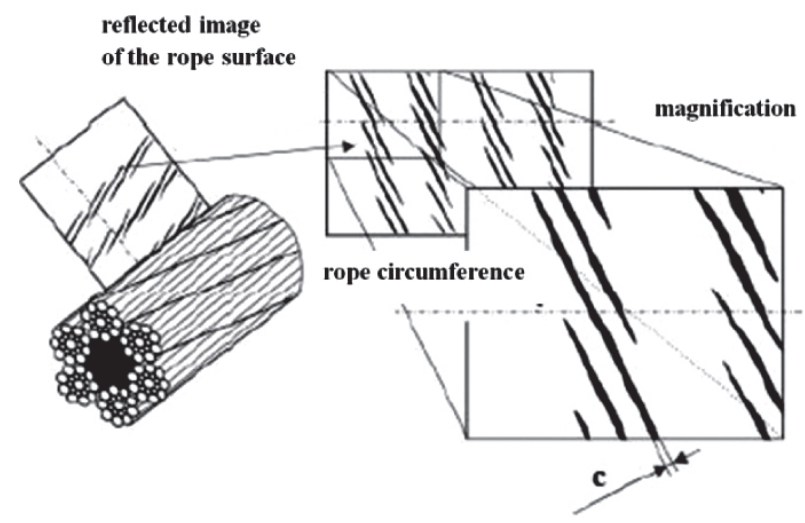

Fig. 2. Measurement of the size of the wire wear using the ,in print" method of the rope surface reflection [8]

\subsubsection{Apparatus methods - magnetic testing}

Magnetic testing is the most common method of testing hoisting ropes in an apparatus. Poland was the first country to introduce a legal obligation in its mines to test the magnetic ropes of hoisting devices. Today's regulations also require magnetic testing of balance and guide ropes.

During the test, the rope becomes magnetized with a permanent field. The magnetic flux flowing through the rope is generated by permanent magnets. An inductive sensor (measuring coil) is located between the pole pieces on the part of the rope that is magnetized. The instantaneous value of the magnetic flux associated with the measuring coil changes when the section of rope on which the damage is moved. As a result of this phenomenon, an electromotive force is induced, the value of which is directly proportional to the change in the ferromagnetic cross-section of the tested rope. The value of this force is also influenced by many factors depending on the measuring head and the parameters of rope damage. Part of the magnetic flux induced by permanent magnets flows through the area surrounding the rope. This part of the stream is called the leakage stream. The lines of the scattering flux are parallel to each other, provided that there is no change in the ferromagnetic cross-section of the tested rope on the magnetized section (Fig. 3) [8].

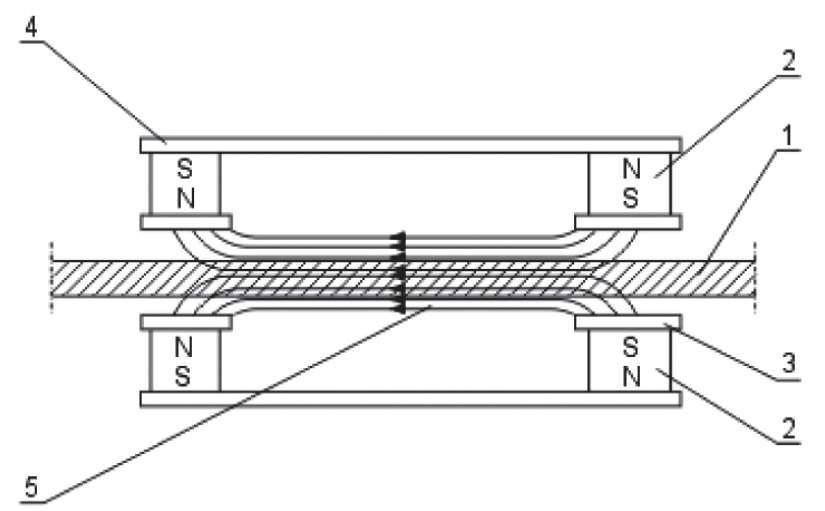

Fig. 3. Distribution of the magnetic field lines in an undamaged line [6]

1 -rope, 2 - permanent magnets, 3 - pole pieces, 4 - jumper, 5 - scattering flux

If there is a step change in the rope cross-section (corrosion pits, cracks etc.) or a change in the homogeneous structure of the line occurs, the magnetic field force lines are deformed. However, the value of the magnetizing flux does not change (Fig. 4).

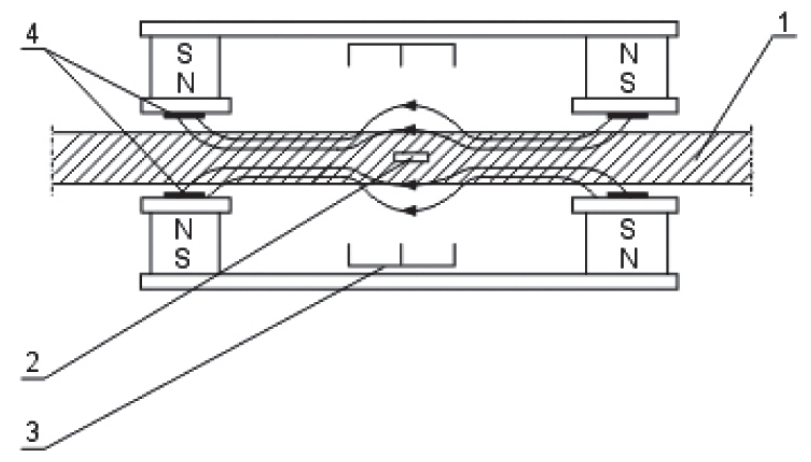

Fig. 4. Distribution of the magnetic field in the damaged line [6]

1 - rope, 2 - rope damage, 3 -inductive sensor for step changes in cross-section, 4 - hall sensor for cross-section changes

The most important parameters affecting the nature and value of the impulse induced in the measuring coil include: the distance between the ends of the broken wire, the damage distance from the rope axis, and the loss of the ferromagnetic cross-section of the tested rope.

The same method is used for magnetic testing of hoisting ropes - rope magnetization with permanent magnets. However, different manufacturers use different types of sensors. Depending on the number and type of detection sensors, the design of magnetic 
concentrators, susceptibility to magnetization, and the principle of operation of the sensor, they provide different signals. Inductive sensors and Hall sensors are the most commonly used detection elements. The main task of an inductive sensor is to detect and measure spike failures. If it is used, the damage should move in relation to the sensor. Hall sensors are also used, which enable the measurement of the so-called continuous damage such as wire abrasion or corrosion. They are also used to increase the detection of damages such as corrosion pits or wire breaks [6].
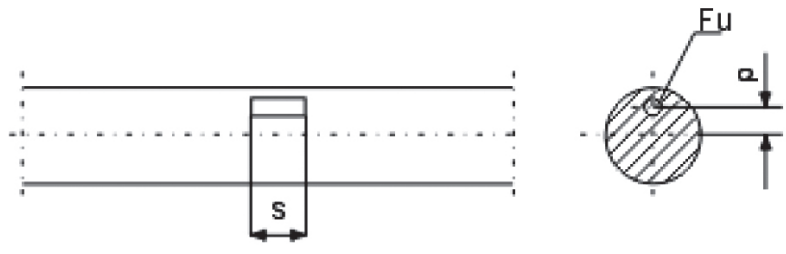

Fig. 5. Parameters influencing the pulse induced in the coil [3]

$S$ - length of the gap between the ends of the broken wire, Fu-ferromagnetic section loss, $\alpha$-radial distance from the rope axis

They can be used as external or internal sensors. The data on the components of the radial force lines of the magnetic field are collected by an external sensor. It should be located at an appropriate distance from the tested rope by the armature. Using information from sensors: external and internal, it is possible to obtain data on the depth of the defect occurrence in the tested line (Fig. 5). If the defect is deep in the line, the values from both sensors have a similar value. If the value of the signal from the external sensor is lower than the value of the signal from the internal sensor, the defect is located in the outer layer of the rope. These solutions are considered to be the best detection of a significant part of typical rope failures $[1,9]$.

The apparatus for performing magnetic flaw detection consists of two elements: the measuring head and the signal output recorder (Fig. 6). The result of the test is a defectogram on which the test results are recorded. The apparatus is equipped with an additional system whose task is to balance the speed changes. The ejection of the tape on which the results are recorded is adjusted to the rope speed. As a result, the signal coming from the sensors and recorded on the tape does not depend on this speed. The measuring head should be calibrated by an independent person, in accordance with the standards, every 3 years [9].

The rope speed has no effect on the accuracy of the measurement, if a compensation system for this value is used.

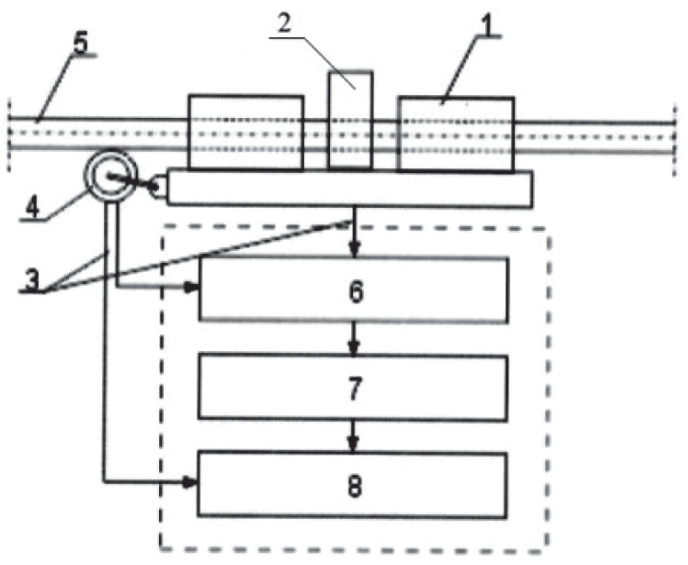

Fig. 6. Diagram of the measuring apparatus mounted on the rope [3]

1 - measuring head, 2 - recording part, 3 - connecting wires, 4 - rope movement and displacement sensor roll, 5 - tested rope, 6 - compensation pulley, 7 - signal amplifier, 8 - recorder

Due to its metrological parameters, the MD-120 defectograph shown in Figures 7 and 8 has become very popular.

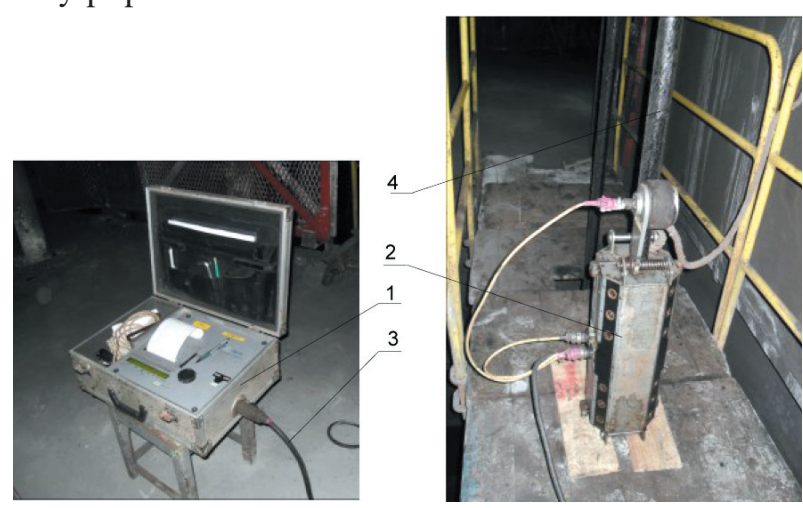

Fig. 7. A set of apparatus for testing round steel ropes 1 - MD-120 recorder, 2 - GP-2 head, 3 - cable connecting the head with the recorder, 4 - tested rope
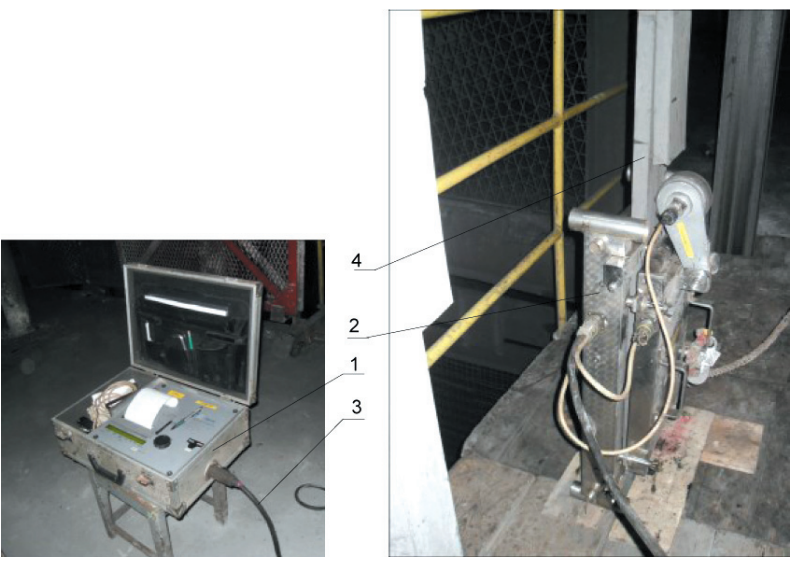

Fig. 8. Set of apparatus for testing steel-rubber ropes 1 - MD-120 recorder, 2 -SAG / LRM head, 3 - cable connecting the head with the recorder, 4 - tested rope 


\section{ANALYSIS OF ROPE WORK IN A SELECTED SHAFT}

Chase characteristics:

- shaft type: exhaust, one-compartment,

- purpose of the shaft: people driving, stone mining,

- extraction levels: framework, level $840 \mathrm{~m}$, level $1000 \mathrm{~m}$,

- shaft diameter: $7.5 \mathrm{~m}$,

- dhaft depth: $1050 \mathrm{~m}$,

- tower height: $27 \mathrm{~m}$ (single-shot turret),

- spine depth: $28 \mathrm{~m}$,

- vessel routing: rigid, double-sided, frontal.

Characteristics of the hoist device:

- Dishes: two years old.

- Useful capacity:

- people rides: $4.5 \mathrm{Mg}$,

- driving with material: $12.0 \mathrm{Mg}$,

- stone mining: $7.5+2.6 \mathrm{Mg}$.

- Diameter of rope pulleys: $5000 \mathrm{~mm}$.

- Type of drive wheel lining: ModarR3.

- Driving speed:

- human travel: $10 \mathrm{~m} / \mathrm{s}$,

- material ride: $10 \mathrm{~m} / \mathrm{s}$,

- stone extraction: $10 \mathrm{~m} / \mathrm{s}$.

- Driving distance: $992.8 \mathrm{~m}$.

Extractor machine:

- Location: felling.

- Type: 2L-5000/2000.

- Year built: 1990.

- Manufacturer: ZUT ZGODA-DOLMEL.

- Motor urine: $2300 \mathrm{Tw}$.

Carrying ropes [1]:

- Number of supporting bales: 2 pieces.

- Marking: 48.0-6×36 WS+FE-S/z-n-1-g 1570.
- Construction: $6(14 \times 2.72+7 \times 1.7 / 7 \times 2.15+$ $7 \times 2.24+1 \times 3.00)+$ FE.

- Ropes work intensity: 180 hauls/day.

- The ropes worked in wet conditions.

Rope wear analysis $[1,10]$.

The supporting ropes in this shaft hoist operated from 27 to 32 months. In all cases, the reason for replacing the ropes was a deterioration of the safety factor due to corrosion. In such cases, magnetic tests are the dominant diagnostic method.

As a result of the survey carried out on May 21, 2015, charts from the defectograph were obtained, which are shown in Figure 9. It was a reason for the decision to replace the ropes. Oxidation of the zinc coating and corrosion raid turning into point pitting corrosion on the entire length of the ropes were found. Moreover, clashes and single factory wire breaks were observed.

The diagnostic methods based on which the decision to replace the ropes was made are:

a) A - visual method, corrosion tarnish and pitting corrosion along the entire length.

b) B! - magnetic method, corrosion raid and progressive pitting corrosion, abrasions and factory shortages of wires.

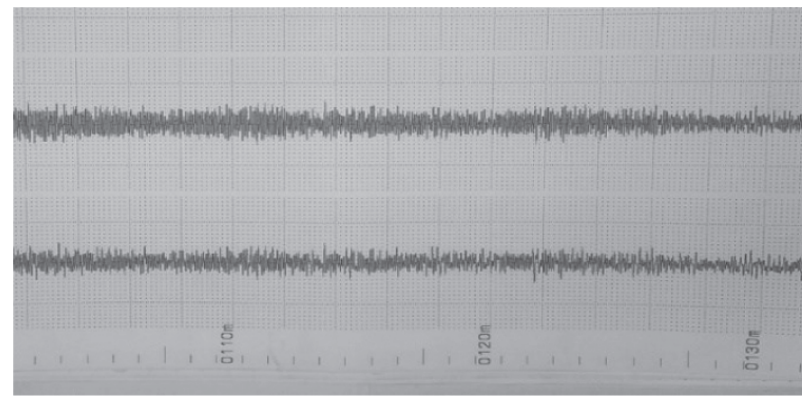

Fig. 9. Fragment of a defectograph from the last test of the rope put aside on February 21, 2015

Table 1

List of lifting ropes in the analyzed shaft [1]

\begin{tabular}{|c|c|c|c|c|c|}
\hline $\begin{array}{c}\text { Set } \\
\text { number }\end{array}$ & Creationdate & $\begin{array}{c}\text { Exchange } \\
\text { date }\end{array}$ & Producer/Wearsymptoms & $\begin{array}{c}\text { Workingtime } \\
\text { [months] }\end{array}$ & $\begin{array}{c}\text { Diagnostic method: } \\
\text { A - visual method, } \\
\text { B! - magnetic method }\end{array}$ \\
\hline 1 & 28.07 .2002 & 23.04 .2005 & $\begin{array}{c}\text { Polskie Liny Sp. z o.o. } \\
\text { w Katowicach/Corrosion }\end{array}$ & 32 & $\begin{array}{c}\text { B! } \\
\text { A }\end{array}$ \\
\hline 2 & 24.04 .2005 & 26.10 .2007 & $\begin{array}{c}\text { Polskie Liny Sp. z o.o. } \\
\text { w Katowicach/Corrosion }\end{array}$ & 30 & $\begin{array}{c}\text { B! } \\
\text { A }\end{array}$ \\
\hline 3 & 27.10 .2007 & 16.05 .2010 & $\begin{array}{c}\text { ŽDB a.s. Bohumin - } \\
\text { Czech Republic/Corrosion }\end{array}$ & 31 & $\begin{array}{c}\text { B! } \\
\text { A }\end{array}$ \\
\hline 4 & 17.05 .2010 & 8.12 .2012 & $\begin{array}{c}\text { ŽDB a.s. Bohumin- } \\
\text { Czech Republic/Corrosion }\end{array}$ & 31 & $\begin{array}{c}\text { B! } \\
\text { A }\end{array}$ \\
\hline 5 & 9.12 .2012 & 14.03 .2015 & $\begin{array}{c}\text { ŽDB a.s. Bohumin - } \\
\text { Czech Republi/Corrosion }\end{array}$ & 27 & $\begin{array}{c}\text { B! } \\
\text { A }\end{array}$ \\
\hline 6 & 15.03 .2015 & 15.11 .2017 & $\begin{array}{c}\text { ŽDB a.s. Bohumin- } \\
\text { Czech Republic/Corrosion }\end{array}$ & 32 & $\begin{array}{c}\text { B! } \\
\text { A }\end{array}$ \\
\hline
\end{tabular}




\section{ASSESSMENT CRITERIA OF LOADING ROPES}

The considered criterion for assessing the durability of ropes is the rope service life index " $\mathrm{T}$ ", expressed in $[\mathrm{MNm} / \mathrm{kg}]$. Ropes of similar construction, but operating in different conditions, have a different service life. This coefficient is used to compare their "workload". For hoisting devices, it is given by Meebold's formula [2, 9]:

$$
T=\frac{N \cdot Q}{100 \cdot q_{i} \cdot i_{n}}
$$

where:

$$
\begin{aligned}
& N-\text { number of work cycles of the extract, } \\
& q_{i}-\text { mass of one running meter of the lifting rope } \\
& \quad[\mathrm{kg} / \mathrm{m}], \\
& i_{n}-\text { number of lifting ropes, } \\
& Q-\text { maximum allowable rope load }[\mathrm{MN}] .
\end{aligned}
$$

The maximum load on the rope comes from: the weight of the vessel with its suspension on the lifting rope or ropes, the guides, the suspension of the rope or balance ropes, the maximum weight of the transported load, the weight of the rope overhang or the lifting and balance ropes.

\section{CALCULATION OF THE WORKING TIME INDEX OF ROPES WORKING IN A SELECTED SHAFT}

Table 2 presents the number of cycles and the value of the work index for successive sets of ropes working in shaft VI. The following data was adopted for the calculations:

- maximum static load on the lifting rope: $Q=429 \mathrm{kN}$,

- weight of one meter of the lifting rope: $q_{i}=8.7 \mathrm{~kg} / \mathrm{m}$.

\section{EXTENSION OF SERVICE ROPES}

In order to observe the elongation of the lifting ropes during operation, their elongation as a function of the number of cycles worked is examined. The relative elongation of the rope is expressed by the relationship (Tab. 2) whereas Figure 10 shows the indicators of working time $T$ for individual sets of ropes in the VI shaft [4]:

$$
\varepsilon=\frac{\Delta L}{l} \cdot 100 \%
$$

where:

$\varepsilon$ - rope relative elongation $[\%]$,

$\Delta L$ - absolute rope elongation [m],

$l$ - length of the working rope $[\mathrm{m}]$.

Table 2

The number of cycles and the value of the working time index for successive sets of ropes in operation in the western section of the selected mining shaft [1]

\begin{tabular}{|c|c|c|}
\hline Number of the next set of ropes & Number of lift cycles & $\begin{array}{c}\text { Rope operating time indicator } \\
\boldsymbol{T}[\mathbf{M N m} / \mathbf{k g}]\end{array}$ \\
\hline 1 & 123573 & 3046.7 \\
\hline 2 & 100853 & 2486.5 \\
\hline 3 & 88621 & 2185.0 \\
\hline 4 & 94156 & 2321.4 \\
\hline 5 & 95019 & 2342.7 \\
\hline
\end{tabular}

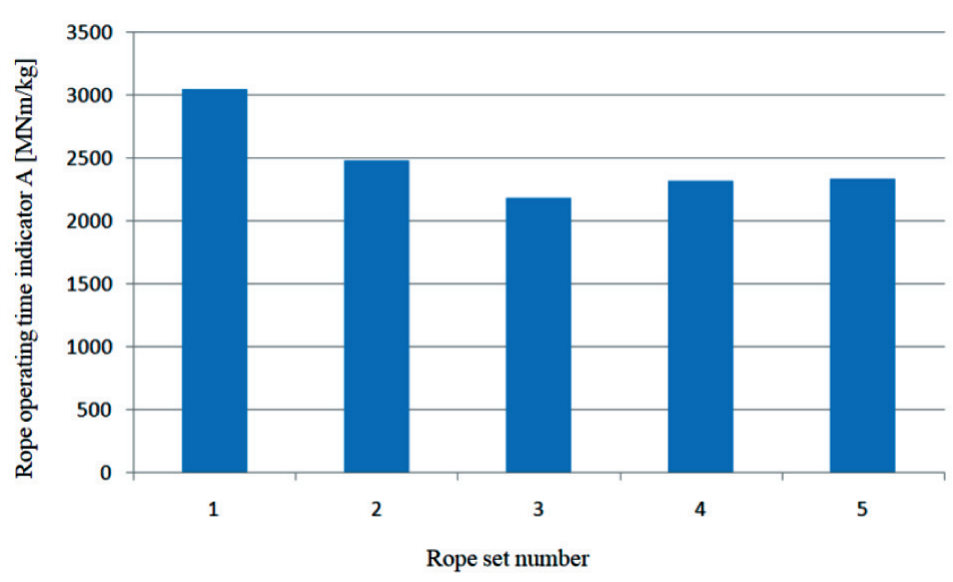

Fig. 10. Indicators of working time T for individual sets of ropes, shafts VI 


\subsection{Service life of ropes operating} in the analyzed hoist of the selected shaft

\subsubsection{A set of ropes operating in the period} from May 17, 2010 to December 8, 2012

Eastern rope $\varnothing 48.0 \mathrm{~mm}$, marked $48.0-6 \times 36$ WS+FE-S/z-n-l-g 1570, during operation it was ex- tended by a total of $3.95 \mathrm{~m}$. The course of rope operation as a function of the number of hoisting cycles and time index the work is summarized in Table 3.

Western rope $\varnothing 48.0 \mathrm{~mm}$, marked 48.0-6×36 WS+FE-Z/s-n-l-g 1570, during operation it was extended by a total of $3.95 \mathrm{~m}$. The course of rope operation as a function of the number of hoisting cycles and time index the work is summarized in Table 4.

Table 3

The course of rope operation as a function of the number of hoisting cycles, eastern rope, set 4 [1]

\begin{tabular}{|c|c|c|c|c|}
\hline $\begin{array}{c}\text { Rope working time } \\
\text { [months] }\end{array}$ & $\begin{array}{c}\text { Number of lift } \\
\text { cycles }\end{array}$ & $\begin{array}{c}\text { Indicator } \boldsymbol{T} \\
{[\mathbf{M N m} / \mathbf{k g}]}\end{array}$ & $\begin{array}{c}\text { Length of the cut } \\
\text { rope } \Delta \boldsymbol{L}[\mathbf{m}]\end{array}$ & $\varepsilon[\%]$ \\
\hline 1 & 2851 & 70 & 2.05 & 0.18 \\
\hline 6 & 16995 & 419 & 3.45 & 0.31 \\
\hline 12 & 34587 & 852 & 3.65 & 0.32 \\
\hline 18 & 50756 & 1251 & 3.85 & 0.34 \\
\hline 24 & 68845 & 1897 & 3.95 & 0.35 \\
\hline 30 & 83965 & 2070 & 3.95 & 0.35 \\
\hline
\end{tabular}

Table 4

Course of rope operation as a function of the number of rope hoists' cycles, west rope, set 4 [1]

\begin{tabular}{|c|c|c|c|c|}
\hline $\begin{array}{c}\text { Rope working time } \\
\text { [months] }\end{array}$ & $\begin{array}{c}\text { Number of lift } \\
\text { cycles }\end{array}$ & $\begin{array}{c}\text { Indicator } \boldsymbol{T} \\
{[\mathbf{M N m} / \mathbf{k g}]}\end{array}$ & $\begin{array}{c}\text { Length of the cut } \\
\text { rope } \Delta \boldsymbol{L}[\mathbf{m}]\end{array}$ & $\varepsilon[\%]$ \\
\hline 1 & 2851 & 70 & 2.05 & 0.18 \\
\hline 6 & 16995 & 419 & 3.25 & 0.29 \\
\hline 12 & 34587 & 852 & 3.55 & 0.31 \\
\hline 18 & 50756 & 1251 & 3.85 & 0.34 \\
\hline 24 & 68845 & 1897 & 3.85 & 0.34 \\
\hline 30 & 83965 & 2070 & 3.95 & 0.35 \\
\hline
\end{tabular}

\subsubsection{A set of ropes for operation in the period} from 12/09/2012 to 03/14/2014 (set 5)

East rope $\varnothing 48.0 \mathrm{~mm}$, marked 48.0-6×36 WS+FE -S/z-n-l-g 1570, during operation it was elongated by a total of $4.1 \mathrm{~m}$. The course of operation of the east- ern and western ropes as a function of the number of extract cycles and the working time index are summarized in Table 6 .

Figures 11-14 show the characteristics of the dependence of the rope elongation $\varepsilon$ as a function of the number of hoisting cycles worked.

Table 5

The course of rope operation as a function of the number of hoisting cycles, eastern rope, set 5 [1]

\begin{tabular}{|c|c|c|c|c|}
\hline $\begin{array}{c}\text { Rope working time } \\
\text { [months] }\end{array}$ & $\begin{array}{c}\text { Number of lift } \\
\text { cycles }\end{array}$ & $\begin{array}{c}\text { Indicator } \boldsymbol{T} \\
{[\mathbf{M N m} / \mathbf{k g}]}\end{array}$ & $\begin{array}{c}\text { Length of the cut } \\
\text { rope } \Delta \boldsymbol{L}[\mathbf{m}]\end{array}$ & $\varepsilon[\%]$ \\
\hline 1 & 3658 & 90 & 2.0 & 0.18 \\
\hline 8 & 30102 & 742 & 3.5 & 0.31 \\
\hline 12 & 46011 & 1135 & 3.8 & 0.34 \\
\hline 18 & 66780 & 1648 & 3.8 & 0.34 \\
\hline 27 & 92582 & 2285 & 4.0 & 0.35 \\
\hline
\end{tabular}


Table 6

The course of rope operation as a function of the number of rope hoists cycles, west rope, set 5 [1]

\begin{tabular}{|c|c|c|c|c|}
\hline $\begin{array}{c}\text { Rope working time } \\
\text { [months] }\end{array}$ & $\begin{array}{c}\text { Number of lift } \\
\text { cycles }\end{array}$ & $\begin{array}{c}\text { Indicator } \boldsymbol{T} \\
{[\mathbf{M N m} / \mathbf{k g}]}\end{array}$ & $\begin{array}{c}\text { Length of the cut } \\
\text { rope } \Delta \boldsymbol{L}[\mathbf{m}]\end{array}$ & $\varepsilon[\%]$ \\
\hline 1 & 3658 & 90 & 2.1 & 0.19 \\
\hline 8 & 30102 & 742 & 3.6 & 0.32 \\
\hline 12 & 46011 & 1135 & 3.9 & 0.35 \\
\hline 18 & 66780 & 1648 & 3.9 & 0.35 \\
\hline 27 & 92582 & 2285 & 4.1 & 0.36 \\
\hline
\end{tabular}

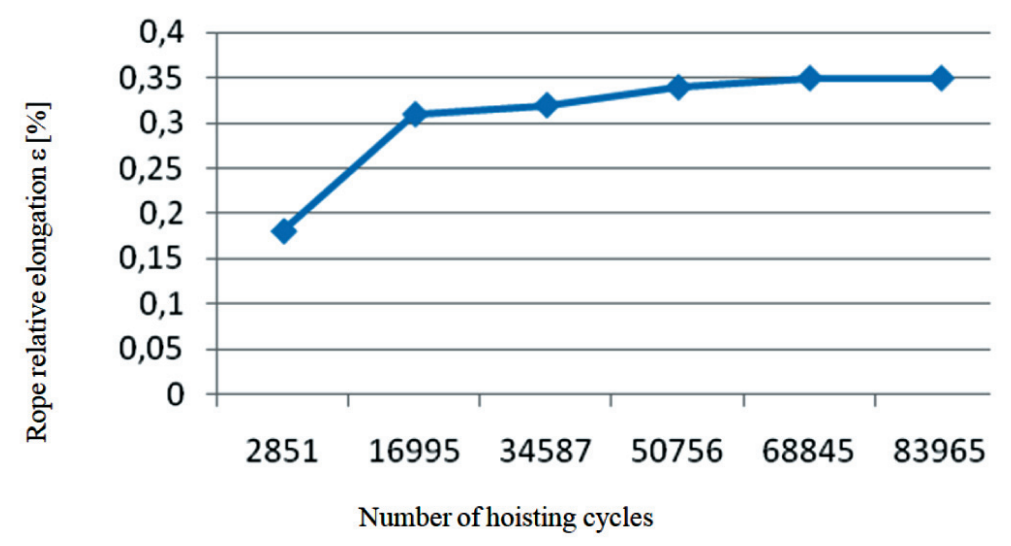

Fig. 11. Graph of the relative elongation of the rope $\varepsilon$ as a function of the number of hoisting cycles, eastern rope set 4

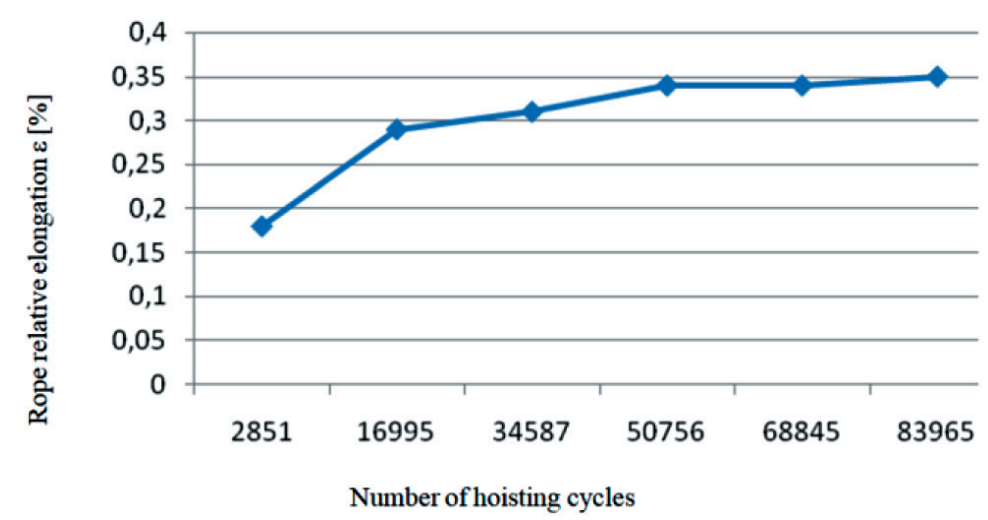

Fig. 12. Graph of the relative elongation of the rope $\varepsilon$ as a function of the number of hoisting cycles, west rope set 4

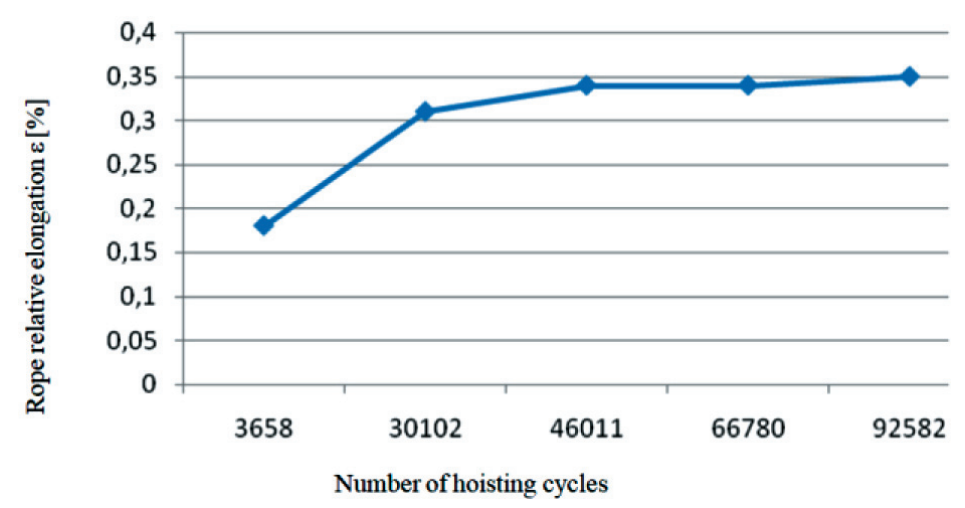

Fig. 13. Graph of the relative elongation of the rope $\varepsilon$ as a function of the number of hoisting cycles, eastern rope set 5 


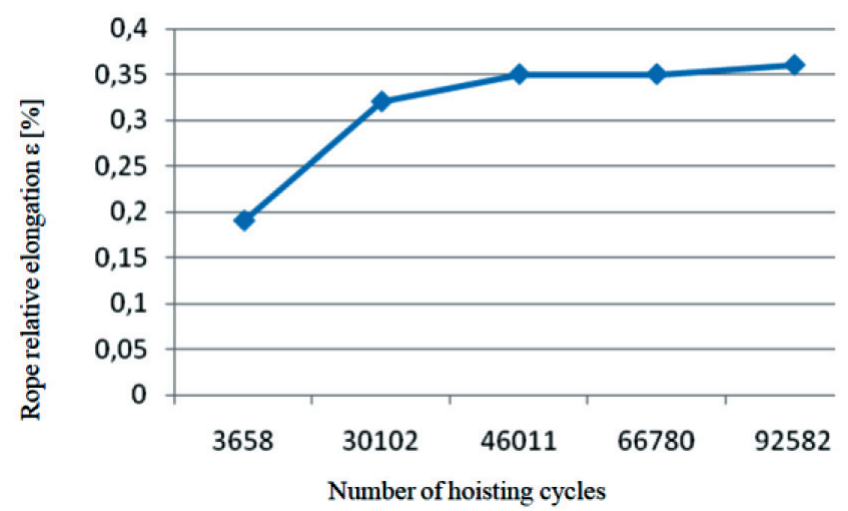

Fig. 14. Diagram of the relative elongation of the rope $\varepsilon$ as a function of the number of hoisting cycles, west rope set 5

\section{SUMMARY}

Based on the analysis carried out in this article, the following conclusions can be drawn $[5,7,10]$ :

- The load-bearing ropes used in one of the analyzed mines in shaft hoists mainly wear due to corrosion. In order to extend their service life, the frequency of the relubrication of the ropes should be increased.

- Bearing ropes working in hoisting devices with the machine located on the framework not only wear as a result of corrosion, but also as a result of the abrasions of the outer layer wires. This is due to the design of the hoisting device where the rope runs over the steering wheel at an angle.

- In each of the analyzed shaft hoists, the ropes were the most elongated in the first 6 months of operation. This elongationis between $62 \%$ and $90 \%$ of the total elongation.

- Ropes of the same construction, working in the same shaft hoist, but with a higher work index, are subject to greater elongation.

- Following further research, the results of which were not presented in this article, it was also found that steel-rubber compensating ropes operating in shaft hoists in one of the mines under consideration wear mainly as a result of corrosion. It especially occurs as a result of damage to the rubber coating. In order to extend their service life, the period between the detection of damage to the rubber coating and the vulcanization should be shortened.
References

[1] Carbogno A., Żołnierz M.: Badania momentu odkrętnego lin wyciagowych, "Zeszyty Naukowe Politechniki Śląskiej. Seria Górnictwo" 2007, 280: 219-229.

[2] Hankus J.: Budowa i własności mechaniczne lin stalowych, Główny Instytut Górnictwa, Katowice 2000.

[3] Kedziora A.: Eksploatacja szybowych urzadzeń wyciagowych, Wydawnictwo Śląsk, Katowice 1983.

[4] Tytko A.: Eksploatacja lin stalowych, Wydawnictwo Śląsk, Katowice - Warszawa 2003.

[5] Darling P. ed.: SME Mining Engineering Handbook. $3^{\text {rd }}$ ed., 2011.

[6] Hansel J., Kwaśniewski J., Lankosz L., Tytko A.: Badania magnetyczne lin stalowych, Wydawnictwa AGH, Kraków 1990.

[7] Kwaśniewski J.: Badania magnetyczne lin stalowych. System certyfikacji personelu w metodzie MTR, Wydawnictwa AGH, Kraków 2010.

[8] Tytko A., Nowacki J.: Abrasive wear of external wires of mining hoist ropes, The International Journal of Transport and Logistics, 2010, 10: 101-105.

[9] Hankus J., Szołtysik P. i in.: Metoda oceny czasu pracy lin w oparciu o wskaźnik meganiutonometrów (tonokilometrów): (wzory, zasady stosowania, przykłady obliczania), Główny Instytut Górnictwa. Instytut Nowych Technik Górniczych i Atestacji, Katowice 1982.

[10] Rozporzadzenie Ministra Gospodarki z dnia 28 czerwca 2002 r. $w$ sprawie bezpieczeństwa $i$ higieny pracy, prowadzenia ruchu oraz specjalistycznego zabezpieczenia przeciwpożarowego w podziemnych zakładach górniczych, Dz.U. z 2002 r., nr 139, poz. 1169.

MICHAE STAWOWIAK, Ph.D., Eng. Department of Mining Mechanization and Robotization

Faculty of Mining, Safety Engineering and Industrial Automation

Silesian University of Technology ul. Akademicka 2, 44-100 Gliwice, Poland michal.stawowiak@polsl.pl

ZENON ROŻENEK, Ph.D., Eng.

KAZ Serwis Sp. z o.o.

ul. Jasna 3B1, 44-122 Gliwice, Poland z.rozenek@kaz-serwis.pl

(C) 2019 Authors. This is an open access publication, which can be used, distributed and reproduced in any medium according to the Creative Commons CC-BY 4.0 License. 


\title{
Ocena trwałości lin pracujących w górniczych wyciągach szybowych
}

\begin{abstract}
$W$ artykule przedstawiono problematykę trwałości lin nośnych i wyrównawczych eksploatowanych $w$ wybranych szybach kopaln głębinowych. Opisano podstawowe przyczyny zużywania się lin wyciagowych, podano metody oceny zużycia lin stalowych, przedstawiono także kryteria oceny trwałości lin nośnych wyciagowych. Autor zaprezentowat również wybrane wyniki z wydtużeń lin nośnych wyciagowych. Artykut zakończony jest wnioskami wynikającymi z przeprowadzonych badań. Artykut zostat także opatrzony zdjęciami przedstawiającymi aparaturę pomiarowa, wykorzystywana do oceny trwałości lin stalowych oraz stalowo-gumowych. W artykule przytoczono zostaty kryteria oceny trwatości lin nośnych.
\end{abstract}

Słowa kluczowe: eksploatacja, liny, ocena, trwatość

\section{WPROWADZENIE}

Górnicze urządzenia wyciągowe stanowią najważniejsze ogniwo i są podstawowym środkiem transportu w polskim górnictwie węgla kamiennego. Za pomocą tych urządzeń odbywa się transport wydobytego urobku z podziemi kopalń. Urządzenia wyciągowe pełnią też szereg innych funkcji, takich jak zjazd i wyjazd załogi oraz opuszczanie różnego rodzaju materiałów niezbędnych do eksploatacji złoża, a także utrzymywania infrastruktury kopalni [1].

Zmniejszająca się liczba złóż węgla zalegających w dogodnych warunkach górniczo-geologicznych oraz stale zwiększająca się głębokość eksploatacji wpływa na wzrost kosztów wydobycia. Jeśli dodamy do tego relatywnie niskie ceny węgla na światowych rynkach, to wyłania się rzeczywisty obraz górnictwa węgla kamiennego w Polsce i na świecie. Szansą na polepszenie opłacalności eksploatacji, a co za tym idzie: utrzymanie rentowności polskich kopalń, jest wzrost koncentracji wydobycia. Opisany powyżej stan przyczynia się do konieczności stosowania coraz bardziej wydajnych i niezawodnych urządzeń wyciągowych. Można to osiągnąć, stosując naczynia wyciągowe o coraz większej pojemności, a także prędkości jazdy w szybach wyciągowych. Skutkiem tego typu działań jest wzrost parametrów pracy lin, co ma wpływ na zmniejszenie ich trwałości [1-3].

Liny stalowe stosowane w wyciagach szybowych ulegają różnym procesom zużyciowym. Wpływają one na zmianę ich parametrów mechanicznych, w rezultacie tracą one swoje właściwości eksploatacyjne. Liny podlegają nieliniowym w funkcji czasu procesom zużyciowym. Skutkom przewidywalnego zużycia próbuje się przeciwdziałać, prowadząc regularne badania oraz kontrole różnymi metodami: od wizualnych do nieniszczących [3-5].

Aby lepiej poznać procesy zużyciowe lin, przydatne może okazać się przeprowadzenie analizy ich trwałości. Analizie takiej poddane zostały liny pracujące w wyciągach szybowych zjazdowo-materiałowych) na jednej z wybranych kopalń węgla kamiennego. Źródłem danych były raporty $z$ badań okresowo przeprowadzanych przez rzeczoznawców, książki okresowych kontroli wyciągów szybowych i książki raportów szybowych.

\section{METODY OCENY STANU LIN STALOWYCH}

Do oceny stanu liny będącej w eksploatacji stosuje się kilka metod. Można wśród nich wyróżnić dwie grupy [4]:

- nieaparaturowe - opierają się na przyglądaniu się procesom zużyciowym lub na pomiarach cech geometrycznych liny zmieniających się wraz z jej eksploatacją,

- aparaturowe - polegają na wykorzystaniu specjalistycznej aparatury - najczęściej stosowane są badania magnetyczne [6]. 


\subsection{Metody nieaparaturowe}

\subsubsection{Metoda wizualna}

Metoda ta opiera się na wzrokowej obserwacji stanu dostępnej części liny. To najbardziej rozpowszechniona metoda diagnostyczna do oceny stanu lin. Wymaga ona dużego doświadczenia osoby przeprowadzającej obserwacje. Ze względu na brak jednoznacznych kryteriów metoda ta jest mało obiektywna. Cykliczne zliczanie złomów zmęczeniowych drutów może być wykorzystane do sporządzenia charakterystyki zużycia zmęczeniowego lin [4].

Obserwacje umożliwiają ujawnienie uszkodzeń, takich jak [7]:

- zerwanie splotek,

- korozja,

- pęknięcia drutów,

- zmiana średnicy liny,

- deformacje,

- falistości,

- miejsca mocowania liny.

\subsubsection{Metody pomiaru cech geometrycznych liny}

Najbardziej rozpowszechnioną metodą oceny stanu lin w tej grupie jest rejestracja zmian średnic w wyznaczonym przekroju liny. Odniesieniem jest wymiar nominalny lub rzeczywisty w wyznaczonym przekroju. Rejestracji średnic dokonuje się po pewnym czasie od założenia nowej liny, gdy średnica wyraźnie się ustabilizuje. Zmniejszenie średnicy w danym miejscu w większości przypadków jest związane z uszkodzeniem lub wadą rdzenia. Maleje lub wzrasta wówczas sztywność poprzeczna liny, co ma wpływ na przyspieszenie zużycia zmęczeniowego. Niebezpieczny jest również lokalny wzrost sztywności poprzecznej liny oraz opadanie splotek na rdzeń. Zjawiska te w linach przeginanych mogą prowadzić do złomów zmęczeniowych drutów [4].

Przykład wzoru:

$$
\Delta d=\frac{d-d_{\text {nom }}}{d_{\text {nom }}} \cdot 100 \%
$$

gdzie:

$d_{\text {nom }}$ - średnica nominalna liny $[\mathrm{mm}]$,
$d-$ zmierzona średnica liny [mm].

Kolejną metodą oceny stanu lin w tej grupie jest pomiar długości skoku liny. To długość skoku helisy, którą zakreślają pojedyncze splotki. Skoki lin z rdzeniami stalowymi wynoszą od 7 do 9 średnic nominalnych. W celu zwiększenia dokładności pomiaru dokonuje się na trzykrotnej długości skoku. Należy wykonać go w kilku oznaczonych odcinkach. Odniesieniem jest wymiar rzeczywisty lub nominalny liny w danym miejscu. Pomiar długości skoku liny jest uzasadniony dopiero po określonym czasie, innym dla każdego urządzenia i konstrukcji liny. Zwłoka ta ma na celu stabilizację parametrów sprężystych liny (brak wydłużenia). Gdy po tym okresie długość skoku zmienia się, może to wskazywać na kręcenie się lin. Znacząca różnica długości skoku w porównaniu z wartością nominalną oddziałuje na spadek trwałości zmęczeniowej [4, 7]:

$$
\Delta l=\frac{l_{s}-l_{\text {nom }}}{l_{\text {nom }}} \times 100
$$

gdzie:

$l_{\text {nom }}$ - nominalna długość skoku liny [mm],

$l_{s}-$ mierzona długość skoku liny [mm].

\subsubsection{Metody pomiaru}

wielkości geometrycznych ubytków

Do pomiaru wielkości starć drutów wykorzystywane są trzy metody: metoda pomiaru średnicy liny, metoda pomiaru wymiarów starcia pojedynczego drutu oraz metoda pomiaru powierzchni odbicia liny in print.

Metoda pomiaru średnic wykorzystywana jest w przypadku lin półzamkniętych i zamkniętych. Jest to dla nich jedyna metoda pomiaru tej wielkości. Metoda ta polega na porównaniu średnicy zmierzonej ze średnicą nowej liny.

Metoda pomiaru wymiarów starcia pojedynczego drutu (rys. 1) polega na pomiarze wysokości starcia $h$ lub cięciwy starcia $c$. Pomiar cięciwy starcia jest zadaniem bardzo utrudnionym i obarczonym wielkim błędem. Aby dokonać pomiaru wysokości starcia, konieczne jest wycięcie drutu. Wymiar starcia oblicza się ze wzoru:

$$
\Delta S_{F e}=r^{2} \cdot \arcsin \left(\frac{c}{2 r}\right)-0,5 \cdot \sqrt{r^{2}-0,25 c^{2}}
$$

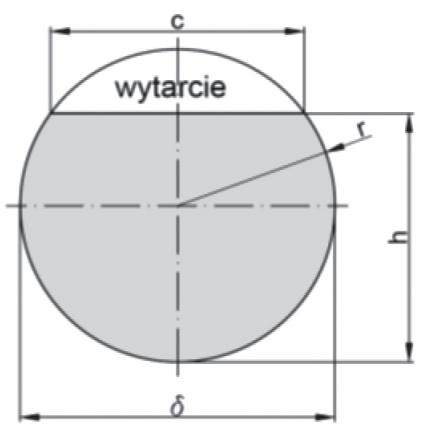

Rys. 1. Obliczanie powierzchni starcia drutu [8] $c$ - cięciwa starcia drutu, $h$-wysokość starcia drutu, $\delta$ - średnica drutu, $r$ - promień $(r=0,5 \cdot \delta)$ 
Bardziej precyzyjną metodą wyznaczania cięciwy starcia drutu jest metoda in print (rys. 2). Polega ona na nałożeniu na wolną od zabrudzeń powierzchnię liny kredy, grafitu lub przeznaczonej do tego celu farby. Po odciśnięciu śladu na papierze otrzymuje się obraz, na którym są dobrze widoczne powierzchnie starcia. Cięciwę starcia można bardzo dokładnie zmierzyć bezpośrednio z odbitki lub z kopii wykonanej w odpowiedniej skali. W celu obliczenia powierzchni startego drutu uzyskaną w ten sposób wielkość cięciwy należy wstawić do wzoru (3). Wartości wyliczone przy użyciu tej metody są zazwyczaj niższe niż wyliczone na podstawie bezpośredniego pomiaru cięciwy starć [1].

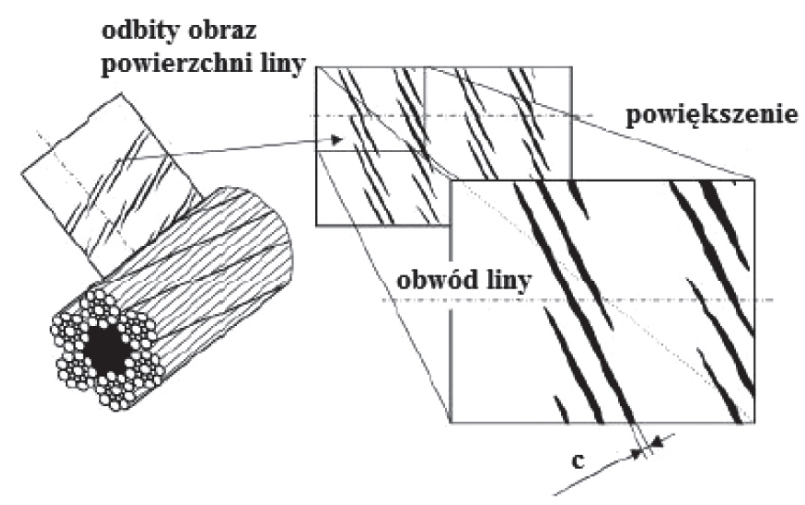

Rys. 2. Pomiar wielkości starć drutów metoda in print odbicia powierzchni liny [8]

\subsubsection{Metody aparaturowe - badanie magnetyczne}

Badanie magnetyczne jest najbardziej rozpowszechnioną aparaturową metodą badania lin wyciągowych. Polska była pierwszym krajem, który wprowadził w swoich kopalniach prawny obowiązek badania magnetycznego lin nośnych urządzeń wyciągowych. Dzisiejsze przepisy wymagają badania magnetycznego również lin wyrównawczych i prowadniczych.

W czasie badania lina zostaje namagnesowana polem stałym. Przepływający przez nią strumień magnetyczny generowany jest przez magnesy trwałe. Na fragmencie liny, który ulega namagnesowaniu, pomiędzy nabiegunnikami ulokowany jest czujnik indukcyjny (cewka pomiarowa). Wartość chwilowa strumienia magnetycznego skojarzona z cewką pomiarową ulega zmianie w momencie przesuwania odcinka liny, na którym znajduje się uszkodzenie. W rezultacie tego zjawiska zostaje wyindukowana siła elektromotoryczna, której wartość jest wprost proporcjonalna do zmiany przekroju ferromagnetycznego badanej liny. Wpływ na wartość tej siły ma również wiele czynników zależnych od głowicy pomiarowej oraz parametrów uszkodzenia liny. Część strumienia magnetycznego indukowanego przez magnesy trwałe przepływa przez obszar otaczający linę. Tę część strumienia nazywa się strumieniem rozproszenia. Linie strumienia rozpro- szenia są do siebie równoległe, pod warunkiem że na magnesowanym odcinku nie występuje zmiana przekroju ferromagnetycznego badanej liny (rys. 3) [8].

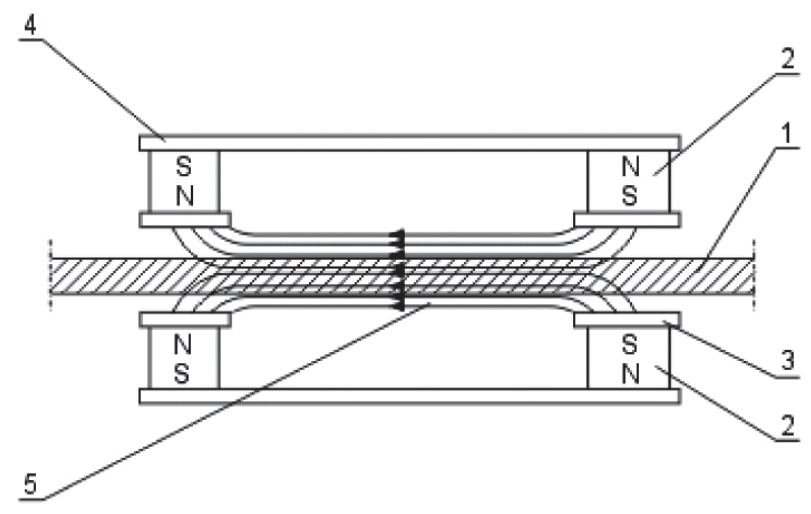

Rys. 3. Rozkład linii pola magnetycznego $w$ nieuszkodzonej linie [6]

1 - lina, 2 - magnesy trwate, 3 - nabiegunniki, 4 - zwora, 5 - strumień rozproszenia

Gdy wystąpi skokowa zmiana przekroju liny (wżery korozyjne, pęknięcia itp.) lub zmiana jednolitej struktury linii, dochodzi do odkształcenia linii sił pola magnetycznego (rys. 4). Nie zmienia się natomiast wartość strumienia magnesującego.

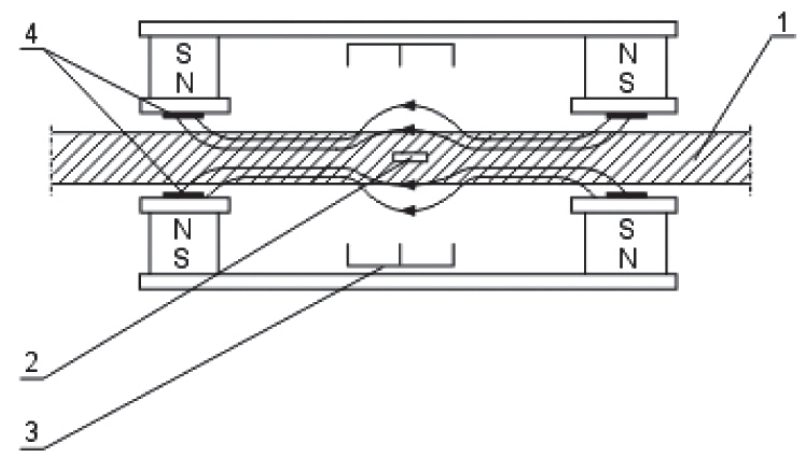

Rys. 4. Rozkład pola magnetycznego w uszkodzonej linie [6]

1 - lina, 2 - uszkodzenie liny, 3 - indukcyjny czujnik pomiarowy skokowych zmian przekroju, 4 - hallotronowy czujnik zmian przekroju

Do najważniejszych parametrów mających wpływ na charakter oraz wartość impulsu indukowanego w cewce pomiarowej należą: odległość między końcami pękniętego drutu, odległość uszkodzenia od osi liny, a także ubytek przekroju ferromagnetycznego badanej liny.

Do badań magnetycznych lin wyciagowych stosuje się tę samą metodę - magnesowanie liny magnesami trwałymi. Jednak różni producenci wykorzystują odmienne rodzaje czujników. W zależności od liczby i rodzaju czujników detekcyjnych, konstrukcji koncentratorów magnetycznych, podatności na magnesowanie i zasady działania czujniki wysyłają inne odmienne sygnały. 
Czujniki indukcyjne i hallotrony to najczęściej stosowane elementy detekcyjne. Podstawowym zadaniem czujnika indukcyjnego jest wykrywanie i pomiar uszkodzeń skokowych. W przypadku jego zastosowania uszkodzenie powinno przemieszczać się względem czujnika. Stosuje się także czujniki hallotronowe, które dają możliwość pomiaru tzw. uszkodzeń ciągłych, takich jak starcia drutów czy korozja. Używa się ich również w celu wzrostu wykrywalności uszkodzeń, takich jak wżery korozyjne lub pęknięcia drutów [6].
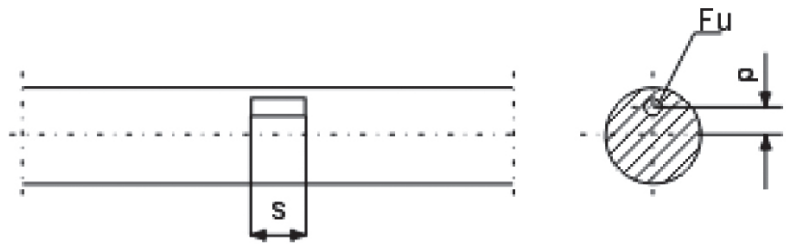

Rys. 5. Parametry wptywajace na impuls indukowany w cewce [3]

$S$ - dlugość szczeliny między końcami pękniętego drutu,

$\mathrm{Fu}$ - ubytek przekroju ferromagnetycznego,

$\alpha$ - promieniowa odległość od osi liny

Mogą one być stosowane jako czujniki zewnętrzne lub wewnętrzne. Dane dotyczące składowych pochodzących od promieniowej linii sił pola magnetycznego są zbierane przez czujnik zewnętrzny. Powinien on być umieszczony w odpowiedniej odległości od badanej liny przy zworze. Na podstawie informacji z czujników: zewnętrznego i wewnętrznego możliwe jest uzyskanie danych dotyczących głębokości wystąpienia wady w badanej linie (rys. 5). Jeśli wada znajduje się głęboko w linie, to wartości pochodzące z obu czujników są zbliżone. W przypadku gdy wartość sygnału z czujnika zewnętrznego jest mniejsza od wartości sygnału pochodzącego z czujnika wewnętrznego, to wada powstała w warstwie zewnętrznej liny. Rozwiązania te uznaje się za najlepsze w wykrywaniu znacznej części typowych uszkodzeń lin $[1,9]$.

Aparatura do wykonywania defektoskopii magnetycznej składa się z dwóch elementów: głowicy pomiarowej oraz rejestratora wyjściowego sygnału (rys. 6). Efektem przeprowadzonego badania jest defektogram, na którym zarejestrowane są wyniki badania. Aparatura wyposażona jest w dodatkowy układ, którego zadaniem jest zrównoważenie zmian prędkości. Wysuw taśmy, na której rejestrowane są wyniki, dostosowany jest do prędkości ruchu liny. W rezultacie sygnał pochodzący z czujników i zapisywany na taśmie nie zależy od tej prędkości. Głowica pomiarowa powinna być kalibrowana przez osobę niezależną zgodnie $\mathrm{z}$ normami co trzy lata [9].

Prędkość badania liny nie ma wpływu na dokładność pomiaru, jeżeli stosuje się układ kompensacji tej wartości.

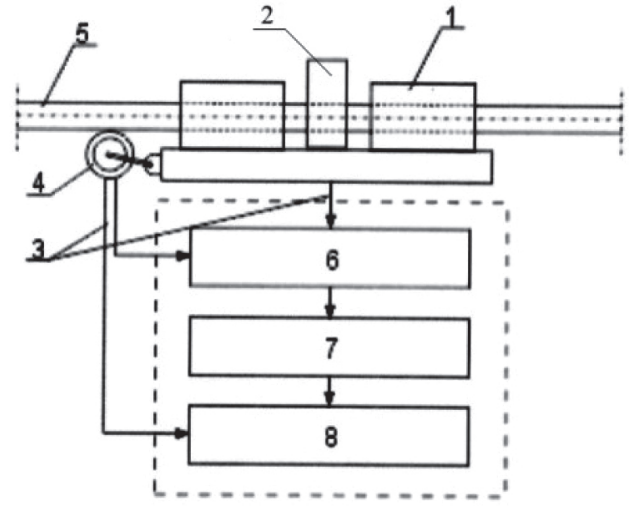

Rys. 6. Schemat aparatury pomiarowej zamontowanej na linie [3]

1 - glowica pomiarowa, 2 - część rejestrująca, 3 - przewody połaczeniowe, 4 - rolka czujnika ruchu i przemieszczenia liny, 5 - badana lina, 6 - krą̇ek kompensacyjny, 7 - wzmacniacz sygnatu, 8 - rejestrator

Dużą popularność ze względu na swoje parametry metrologiczne zyskał defektograf MD-120, który został przedstawiony na rysunkach 7 i 8 .
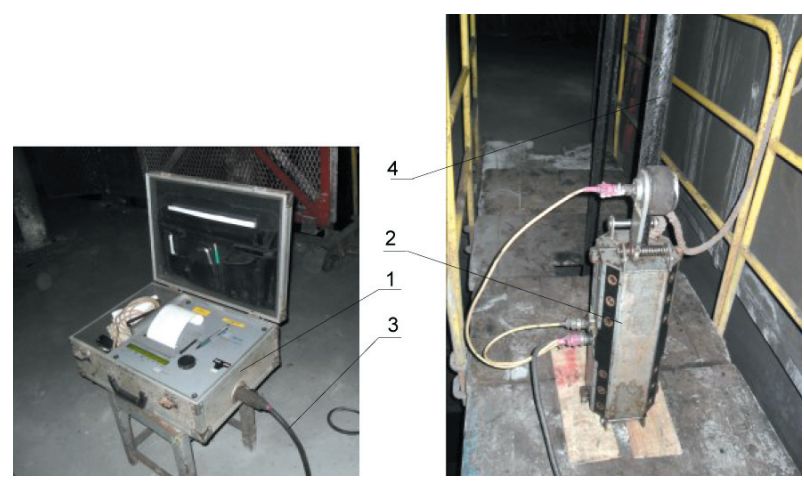

Rys. 7. Zestaw aparatury do badania lin stalowych okragtych

1 - rejestrator MD-120, 2 - głowica GP-2, 3 - przewód taczacy głowice z rejestratorem, 4 - badana lina
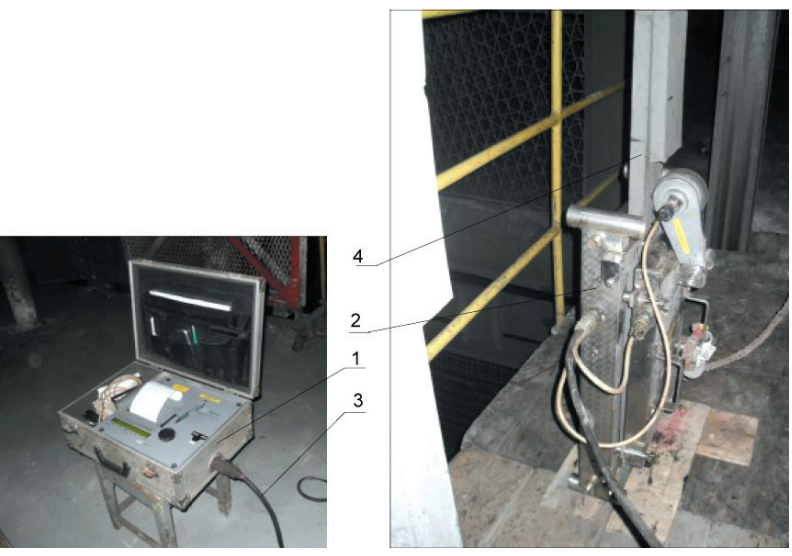

Rys. 8. Zestaw aparatury do badania lin stalowo-gumowych

1 - rejestrator MD-120, 2 - glowica $S A G / L R M, 3$ - przewód taczacy głowice z rejestratorem, 4 - badana lina 


\section{ANALIZA PRACY LIN W WYBRANYM SZYBIE WYDOBYWCZYM}

Charakterystyka szybu:

- Rodzaj szybu: wydechowy, jednoprzedziałowy.

- Przeznaczenie szybu: jazda ludzi, wydobycie kamienia.

- Poziomy wydobywcze: zrąb, poziom 840 m, poziom $1000 \mathrm{~m}$.

- Średnica szybu: 7,5 m.

- Głębokość szybu: 1050 m.

- Wysokość wieży: 27 m (wieża jednozastrzałowa).

- Głębokość rząpia: 28 m.

- Prowadzenie naczyń: sztywne, dwustronne, czołowe.

Charakterystyka urządzenia wyciągowego:

- Naczynia: dwie klatki.

- Udźwig użyteczny:

- jazda ludzi: 4,5 Mg,

- jazda z materiałem: $12,0 \mathrm{Mg}$,

- wydobycie kamienia: 7,5 + 2,6 Mg.

- Średnica kół linowych: $5000 \mathrm{~mm}$.

- Rodzaj wykładziny koła pędnego: Modar R3.

- Prędkość jazdy:

- jazda ludzi: $10 \mathrm{~m} / \mathrm{s}$,

- jazda z materiałem: $10 \mathrm{~m} / \mathrm{s}$,

- wydobycie kamienia: $10 \mathrm{~m} / \mathrm{s}$.

- Droga jazdy: 992,8 m.

Maszyna wyciągowa:

- Lokalizacja: na zrębie.

- Typ: 2L-5000/2000.

- Rok budowy: 1990.

- Wytwórca: ZUT ZGODA-DOLMEL.

- Moc znamionowa silnika: $2300 \mathrm{~kW}$.

Liny nośne [1]:

- Liczba lin nośnych: 2 sztuki.

- Oznaczenie: 48,0-6×36 WS+FE-S/z-n-1-g 1570.
- Konstrukcja: $6(14 \times 2,72+7 \times 1,7 / 7 \times 2,15+7 \times 2,24$ $+1 \times 3,00)+$ FE.

- Natężenie pracy lin: 180 wyciągnięć na dobę.

- Liny pracowały w warunkach mokrych.

Analiza zużycia liny $[1,10]$.

Liny nośne w tym wyciągu szybowym pracowały od 27 do 32 miesięcy. We wszystkich przypadkach powodem wymiany lin było osłabienie współczynnika bezpieczeństwa na skutek korozji. W takich przypadkach dominującą formą diagnostyczną są badania magnetyczne. W tabeli 1 zostały zestawione liny nośne analizowane w przedmiotowym szybie wydobywczym.

W wyniku badania przeprowadzonego 21.05.2015 r. otrzymano wykresy z defektografu, które przedstawiono na rysunku 9, orazpodjęto decyzję o konieczności wymiany lin. Stwierdzono utlenienie powłoki cynkowej i nalot korozyjny przechodzący w punktową korozję wżerową na całej długości lin. Ponadto zaobserwowano starcia i pojedyncze fabryczne pęknięcia drutów.

Metody diagnostyczne, na podstawie których została podjęta decyzja o wymianie lin, to:

- A - metoda wizualna, nalot korozyjny oraz korozja wżerowa na całej długości.

- B! - metoda magnetyczna, nalot korozyjny oraz postępująca korozja wżerowa, starcia oraz braki fabryczne drutów.

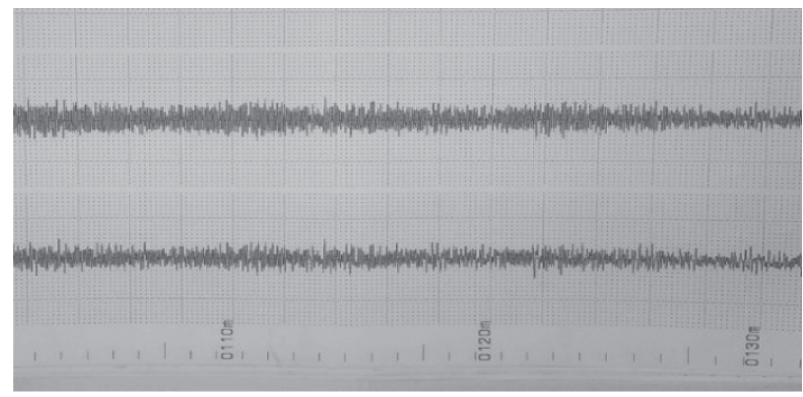

Rys. 9. Fragment defektografu z ostatniego badania liny odtożonej 21.02.2015 r.

Tabela 1

Zestawienie lin nośnych w analizowanym szybie wydobywczym [1]

\begin{tabular}{|c|c|c|c|c|c|}
\hline $\begin{array}{c}\text { Numer } \\
\text { zestawu }\end{array}$ & $\begin{array}{c}\text { Data } \\
\text { zalożenia }\end{array}$ & $\begin{array}{c}\text { Data } \\
\text { wymiany }\end{array}$ & Producent/Symptomy zużycia & $\begin{array}{c}\text { Czas pracy } \\
\text { [miesiące] }\end{array}$ & $\begin{array}{c}\text { Metoda diagnostyczna: } \\
\text { A - metoda wizualna, } \\
\text { B! - metoda magnetyczna }\end{array}$ \\
\hline 1 & 28.07 .2002 & 23.04 .2005 & $\begin{array}{c}\text { Polskie Liny Sp. z o.o. } \\
\text { w Katowicach/Korozja }\end{array}$ & 32 & $\begin{array}{c}\text { B! } \\
\text { A }\end{array}$ \\
\hline 2 & 24.04 .2005 & 26.10 .2007 & $\begin{array}{c}\text { Polskie Liny Sp. z o.o. } \\
\text { w Katowicach/Korozja }\end{array}$ & 30 & $\begin{array}{c}\text { B! } \\
\text { A }\end{array}$ \\
\hline 3 & 27.10 .2007 & 16.05 .2010 & $\begin{array}{c}\text { ŽDB a.s. Bohumin- } \\
\text { Republika Czeska/Korozja }\end{array}$ & 31 & $\begin{array}{c}\text { B! } \\
\text { A }\end{array}$ \\
\hline 4 & 17.05 .2010 & 8.12 .2012 & $\begin{array}{c}\text { ŽDB a.s. Bohumin - } \\
\text { Republika Czeska/Korozja }\end{array}$ & 31 & $\begin{array}{c}\mathrm{B} ! \\
\text { A }\end{array}$ \\
\hline 5 & 9.12 .2012 & 14.03 .2015 & $\begin{array}{c}\text { ŽDB a.s. Bohumin- } \\
\text { Republika Czeska/Korozja }\end{array}$ & 27 & $\begin{array}{c}\text { B! } \\
\text { A }\end{array}$ \\
\hline 6 & 15.03 .2015 & 15.11 .2017 & $\begin{array}{c}\text { ŽDB a.s. Bohumin- } \\
\text { Republika Czeska/Korozja }\end{array}$ & 32 & $\begin{array}{c}\mathrm{B} ! \\
\mathrm{A}\end{array}$ \\
\hline
\end{tabular}




\section{KRYTERIA OCENY LIN NOŚNYCH}

Rozpatrywanym kryterium oceny trwałości lin jest wskaźnik czasu eksploatacji liny $T[\mathrm{MNm} / \mathrm{kg}]$. Liny o podobnej konstrukcji, lecz pracujące w odmiennych warunkach, mają inną żywotność. Współczynnik ten stosowany jest $\mathrm{w}$ celu porównania ich „wytężenia pracy”. Dla urządzeń wyciągowych określany jest wzorem R. Meebolda [2, 9]:

$$
T=\frac{N \cdot Q}{100 \cdot q_{i} \cdot i_{n}}
$$

gdzie:

$N$ - liczba cykli pracy wyciągu,

$q_{i}$ - masa metra bieżącego liny nośnej $[\mathrm{kg} / \mathrm{m}]$,

$i_{n}$ - liczba lin nośnych,

$Q$ - maksymalne dopuszczalne obciążenie liny $[\mathrm{MN}]$.

Maksymalne obciążenie liny pochodzi od masy naczynia $\mathrm{z}$ jego zawieszeniem na linie lub linach nośnych, prowadnic, zawieszenia liny lub lin wyrównawczych, maksymalnej masy transportowanego ładunku, masy zwisu liny lub lin nośnych i wyrównawczych.

\section{OBLICZANIE WSKAŹNIKA CZASU PRACY LIN PRACUJACYCH W WYBRANYM SZYBIE WYDOBYWCZYM}

W tabeli 2 przedstawiono liczbę cykli oraz wartość wskaźnika pracy dla kolejnych zestawów lin pracujących w szybie VI. Do obliczeń przyjęto następujące dane:

- maksymalne statyczne obciążenie liny nośnej: $Q=429 \mathrm{kN}$,

- masa metra bieżącego liny nośnej: $q_{i}=8,7 \mathrm{~kg} / \mathrm{m}$.

\section{WYDKUŻENIE EKSPLOATACYJNE LIN NOŚNYCH}

W celu obserwacji wydłużania lin nośnych podczas eksploatacji bada się ich wydłużenie w funkcji liczby przepracowanych cykli (tab. 2). Natomiast na rysunku 10 przedstawiono wskaźnik czasu pracy $T$ dla poszczególnych zestawów lin w szybie VI. Wydłużenie względne liny wyraża się zależnością [4]:

$$
\varepsilon=\frac{\Delta L}{l} \cdot 100 \%
$$

gdzie:

$\varepsilon$ - wydłużenie względne liny [\%],

$\Delta L$ - wydłużenie bezwzględne liny [m],

$l$ - długość pracującej liny [m].

Tabela 2

Liczba cykli oraz wartość wskaźnika czasu pracy dla kolejnych zestawów lin pracujących w przedziale zachodnim wybranego szybu wydobywczego [1]

\begin{tabular}{|c|c|c|}
\hline Numer kolejnego zestawu lin & Liczba cykli wyciągów & $\begin{array}{c}\text { Wskaźnik czasu pracy lin } \boldsymbol{T} \\
{[\mathbf{M N m} / \mathbf{k g}]}\end{array}$ \\
\hline 1 & 123573 & 3046,7 \\
\hline 2 & 100853 & 2486,5 \\
\hline 3 & 88621 & 2185,0 \\
\hline 4 & 94156 & 2321,4 \\
\hline 5 & 95019 & 2342,7 \\
\hline
\end{tabular}

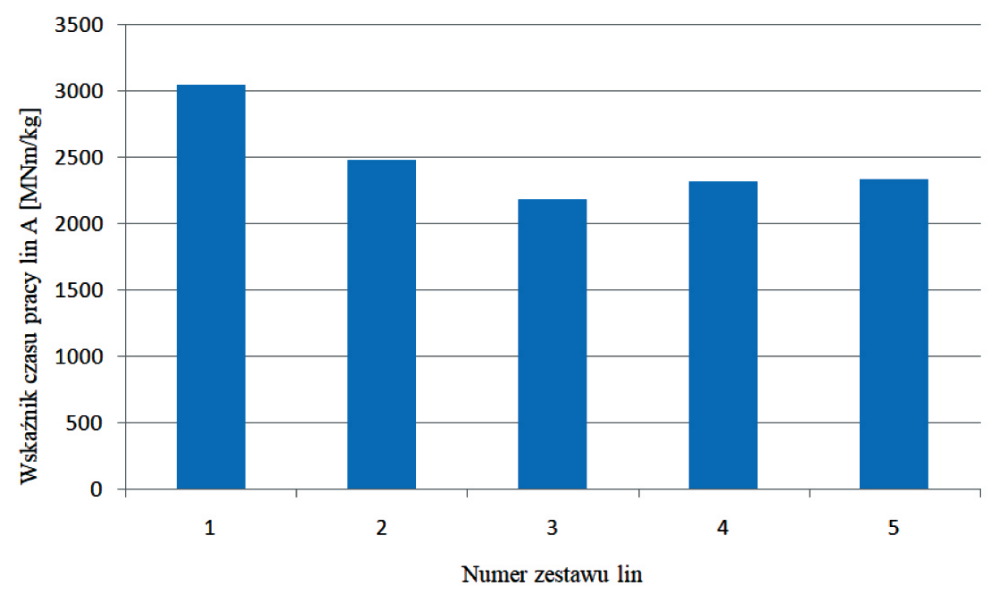

Rys. 10. Wskaźniki czasu pracy T dla poszczególnych zestawów lin, szyb VI 


\subsection{Wydłużenie eksploatacyjne}

lin pracujących $w$ analizowanym wyciągu wybranego szybu wydobywczego

\subsubsection{Zestaw lin pracujący od 17.05.2010 r.} do 8.12.2012 r.

Lina wschodnia $\varnothing 48,0 \mathrm{~mm}$, oznaczona 48,0-6×36 WS+FE-S/z-n-l-g 1570, w czasie eksploatacji uległa wydłużeniu łącznie o 3,95 m. Przebieg pracy liny w funkcji liczby cykli wyciągowych oraz wskaźnika czasu pracy zestawiono w tabeli 3 .

Lina zachodnia $\varnothing 48,0 \mathrm{~mm}$, oznaczona 48,0-6×36 WS +FE-Z/s-n-1-g 1570, w czasie eksploatacji uległa wydłużeniu łącznie o $3,95 \mathrm{~m}$. Przebieg pracy liny w funkcji liczby cykli wyciągowych oraz wskaźnika czasu pracy zestawiono w tabeli 4.

Tabela 3

Przebieg pracy liny w funkcji liczby cykli wyciągów, lina wschodnia, zestaw 4 [1]

\begin{tabular}{|c|c|c|c|c|}
\hline $\begin{array}{c}\text { Czas pracy liny } \\
\text { [miesiące] }\end{array}$ & $\begin{array}{c}\text { Liczba cykli } \\
\text { wyciągów }\end{array}$ & $\begin{array}{c}\text { Wskaźnik } \boldsymbol{T} \\
{[\mathbf{M N m} / \mathbf{k g}]}\end{array}$ & $\begin{array}{c}\text { Długość odciętej liny } \\
\Delta \boldsymbol{L}[\mathbf{m}]\end{array}$ & $\varepsilon[\%]$ \\
\hline 1 & 2851 & 70 & 2,05 & 0,18 \\
\hline 6 & 16995 & 419 & 3,45 & 0,31 \\
\hline 12 & 34587 & 852 & 3,65 & 0,32 \\
\hline 18 & 50756 & 1251 & 3,85 & 0,34 \\
\hline 24 & 68845 & 1897 & 3,95 & 0,35 \\
\hline 30 & 83965 & 2070 & 3,95 & 0,35 \\
\hline
\end{tabular}

Tabela 4

Przebieg pracy liny w funkcji liczby cykli wyciągów, lina zachodnia, zestaw 4 [1]

\begin{tabular}{|c|c|c|c|c|}
\hline $\begin{array}{c}\text { Czas pracy liny } \\
{[\text { miesiące] }}\end{array}$ & $\begin{array}{c}\text { Liczba cykli } \\
\text { wyciągów }\end{array}$ & $\begin{array}{c}\text { Wskaźnik } \boldsymbol{T} \\
{[\mathbf{M N m} / \mathbf{k g}]}\end{array}$ & $\begin{array}{c}\text { Długość odciętej liny } \\
\Delta \boldsymbol{L}[\mathbf{m}]\end{array}$ & $\varepsilon[\%]$ \\
\hline 1 & 2851 & 70 & 2,05 & 0,18 \\
\hline 6 & 16995 & 419 & 3,25 & 0,29 \\
\hline 12 & 34587 & 852 & 3,55 & 0,31 \\
\hline 18 & 50756 & 1251 & 3,85 & 0,34 \\
\hline 24 & 68845 & 1897 & 3,85 & 0,34 \\
\hline 30 & 83965 & 2070 & 3,95 & 0,35 \\
\hline
\end{tabular}

\subsubsection{Zestaw lin pracujacy od $9.12 .2012 \mathrm{r}$.} do 14.03.2014 r.

Lina wschodnia $\varnothing 48,0 \mathrm{~mm}$, oznaczona 48,0-6×36 WS+FE-S/z-n-l-g 1570, w czasie eksploatacji uległa wydłużeniu łącznie o 4,1 m. Przebieg pracy lin wschodniej i zachodniej w funkcji liczby cykli wyciągowych oraz wskaźnika czasu pracy zestawiono w tabelach 5 i 6.

Na rysunkach 11-14 przedstawione zostały charakterystyki zależności wydłużenia względnego lin $\varepsilon$ w funkcji liczby przepracowanych cykli wyciągowych.

Tabela 5

Przebieg pracy liny w funkcji liczby cykli wyciągów, lina wschodnia, zestaw 5 [1]

\begin{tabular}{|c|c|c|c|c|}
\hline $\begin{array}{c}\text { Czas pracy liny } \\
\text { [miesiące] }\end{array}$ & $\begin{array}{c}\text { Liczba cykli } \\
\text { wyciągów }\end{array}$ & $\begin{array}{c}\text { Wskaźnik } \boldsymbol{T} \\
{[\mathbf{M N m} / \mathbf{k g}]}\end{array}$ & $\begin{array}{c}\text { Długość odciętej liny } \\
\Delta \boldsymbol{L}[\mathbf{m}]\end{array}$ & $\varepsilon[\%]$ \\
\hline 1 & 3658 & 90 & 2,0 & 0,18 \\
\hline 8 & 30102 & 742 & 3,5 & 0,31 \\
\hline 12 & 46011 & 1135 & 3,8 & 0,34 \\
\hline 18 & 66780 & 1648 & 3,8 & 0,34 \\
\hline 27 & 92582 & 2285 & 4,0 & 0,35 \\
\hline
\end{tabular}


Tabela 6

Przebieg pracy liny w funkcji liczby cykli wyciągów, lina zachodnia, zestaw 5 [1]

\begin{tabular}{|c|c|c|c|c|}
\hline $\begin{array}{c}\text { Czas pracy liny } \\
\text { [miesiące] }\end{array}$ & $\begin{array}{c}\text { Liczba cykli } \\
\text { wyciągów }\end{array}$ & $\begin{array}{c}\text { Wskaźnik } \boldsymbol{T} \\
{[\mathbf{M N m} / \mathbf{k g}]}\end{array}$ & $\begin{array}{c}\text { Długość odciętej liny } \\
\Delta \boldsymbol{L}[\mathbf{m}]\end{array}$ & $\varepsilon[\mathbf{\%}]$ \\
\hline 1 & 3658 & 90 & 2,1 & 0,19 \\
\hline 8 & 30102 & 742 & 3,6 & 0,32 \\
\hline 12 & 46011 & 1135 & 3,9 & 0,35 \\
\hline 18 & 66780 & 1648 & 3,9 & 0,35 \\
\hline 27 & 92582 & 2285 & 4,1 & 0,36 \\
\hline
\end{tabular}

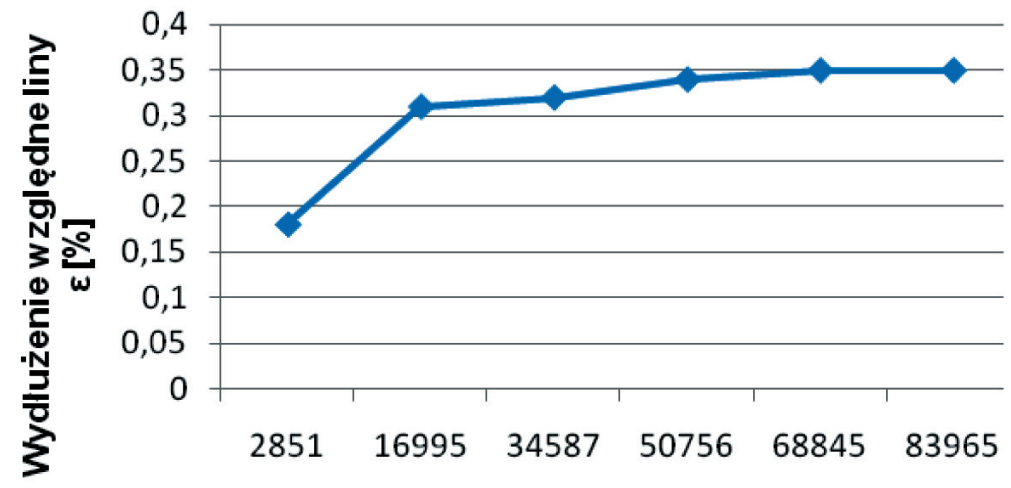

Liczba cykli wyciagowych

Rys. 11. Wykres wydtużenia względnego liny $\varepsilon w$ funkcji liczby cykli wyciagowych, lina wschodnia, zestaw 4

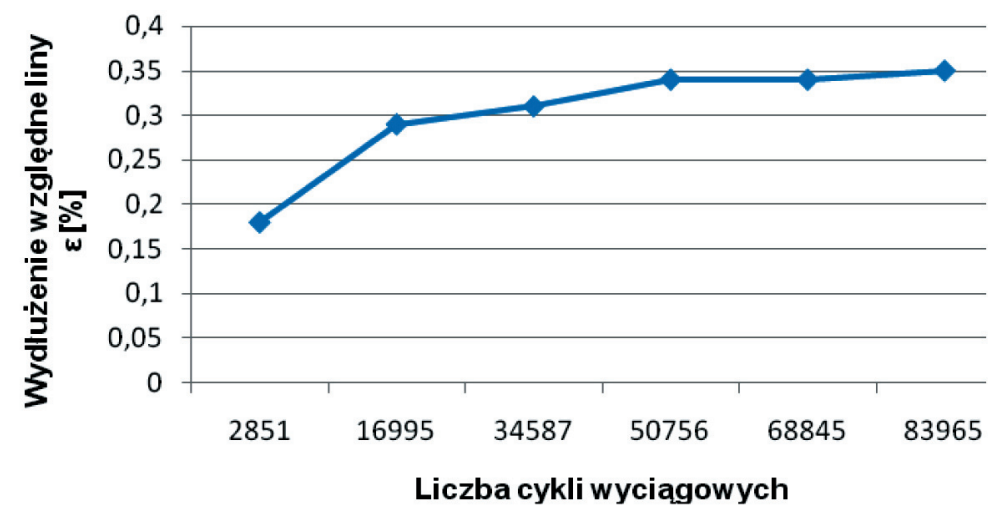

Rys. 12. Wykres wydtużenia względnego liny $\varepsilon w$ funkcji liczby cykli wyciagowych, lina zachodnia, zestaw 4

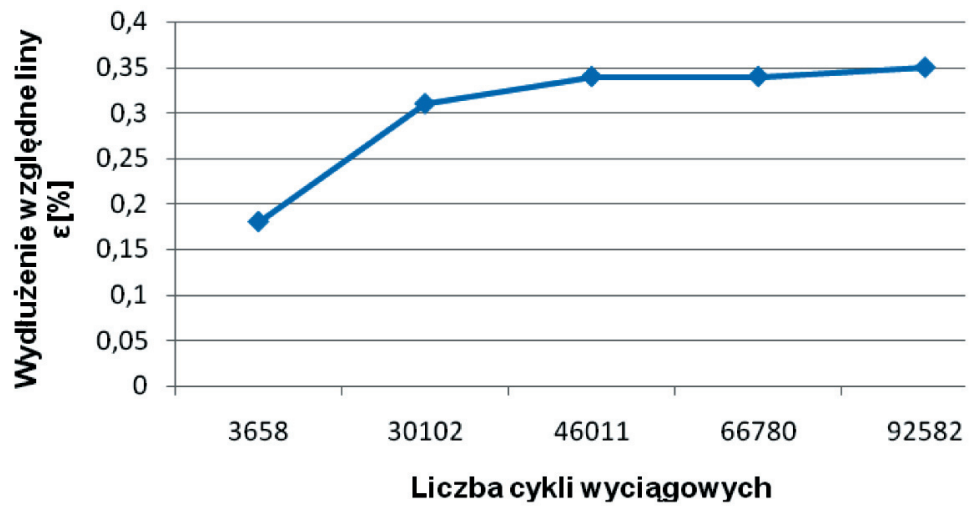

Rys. 13. Wykres wydtużenia względnego liny $\varepsilon w$ funkcji liczby cykli wyciagowych, lina wschodnia, zestaw 5 


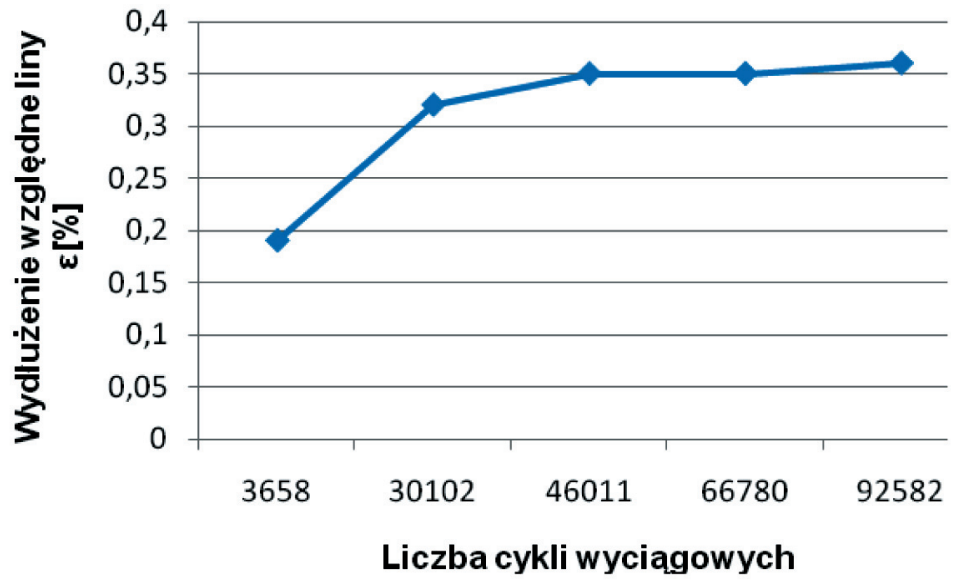

Rys. 14. Wykres wydtużenia względnego liny $\varepsilon w$ funkcji liczby cykli wyciagowych, lina zachodnia, zestaw 5

\section{PODSUMOWANIE}

Na podstawie przeprowadzonej w niniejszym artykule analizy można wyciagnąć następujące wnioski $[5,7,10]$ :

- Liny nośne eksploatowane w jednej z analizowanych kopalń w wyciągach szybowych zużywają się głównie wskutek korozji. Aby wydłużyć ich czas eksploatacji, należy zwiększyć częstotliwość dosmarowywania lin.

- Liny nośne pracujące w urządzeniach wyciągowych z maszyną znajdującą się na zrębie zużywają się nie tylko w wyniku korozji, ale również wskutek starć drutów warstwy zewnętrznej. Wynika to z konstrukcji urządzenia wyciągowego, w którym lina nabiega na koło kierujące pod pewnym kątem.

- W każdym z analizowanych wyciągów szybowych liny uległy największemu wydłużeniu w pierwszych 6 miesiącach eksploatacji. Wydłużenie to wynosi od $62 \%$ do $90 \%$ całkowitego wydłużenia.

- Liny tej samej konstrukcji, pracujące w tym samym wyciągu szybowym, lecz z większym wskaźnikiem pracy ulegają większym wydłużeniom.

- W ślad za dalszymi badaniami, których wyników nie zaprezentowano w niniejszym artykule, stwierdzono także, że liny wyrównawcze stalowo-gumowe pracujace w wyciagach szybowych, w jednej z rozpatrywanych kopalń, zużywają się głównie w wyniku korozji. Dochodzi do niej zwłaszcza z powodu uszkodzenia powłoki gumowej. W celu wydłużenia ich czasu eksploatacji należy skrócić okres między wykryciem uszkodzenia powłoki gumowej a wykonaniem wulkanizacji.
Literatura

[1] Carbogno A., Żołnierz M.: Badania momentu odkrętnego lin wyciagowych, „Zeszyty Naukowe Politechniki Śląskiej. Seria Górnictwo" 2007, 280: 219-229.

[2] Hankus J.: Budowa i własności mechaniczne lin stalowych, Główny Instytut Górnictwa, Katowice 2000.

[3] Kędziora A.: Eksploatacja szybowych urządzeń wyciagowych, Wydawnictwo Śląsk, Katowice 1983.

[4] Tytko A.: Eksploatacja lin stalowych, Wydawnictwo Śląsk, Katowice - Warszawa 2003.

[5] Darling P., ed.: SME Mining Engineering Handbook, wyd. 3, 2011.

[6] Hansel J., Kwaśniewski J., Lankosz L., Tytko A.: Badania magnetyczne lin stalowych, Wydawnictwa AGH, Kraków 1990.

[7] Kwaśniewski J.: Badania magnetyczne lin stalowych. System certyfikacji personelu w metodzie MTR, Wydawnictwa AGH, Kraków 2010.

[8] Tytko A., Nowacki J.: Abrasive wear of external wires of mining hoist ropes, The International Journal of Transport and Logistics 2010, 10: 101-105.

[9] Hankus J., Szołtysik P. i in.: Metoda oceny czasu pracy lin w oparciu o wskaźnik meganiutonometrów (tonokilometrów): (wzory, zasady stosowania, przykłady obliczania), Główny Instytut Górnictwa. Instytut Nowych Technik Górniczych i Atestacji, Katowice 1982.

[10] Rozporządzenie Ministra Gospodarki z dnia 28 czerwca 2002 r. $w$ sprawie bezpieczeństwa $i$ higieny pracy, prowadzenia ruchu oraz specjalistycznego zabezpieczenia przeciwpożarowego w podziemnych zakładach górniczych, Dz.U. z 2002 r., nr 139, poz. 1169.

dr inz. MICHAE STAWOWIAK Katedra Mechanizacji i Robotyzacji Górnictwa Wydziat Górnictwa, Inżynierii Bezpieczeństwa i Automatyki Przemystowej Politechnika Ślaska

ul. Akademicka 2, 44-100 Gliwice michal.stawowiak@polsl.pl

dr inż. ZENON ROŻENEK

KAZ Serwis Sp. z o.o. ul. Jasna 3B1, 44-122 Gliwice z.rozenek@kaz-serwis.pl

(C) 2019 Autorzy. Jest to publikacja ogólnodostępna, którą można wykorzystywać, rozpowszechniać i kopiować w dowolnej formie zgodnie z licencją Creative Commons CC-BY 4.0. 